\title{
路面材料とゴム材料 (アスファルトラバー)
}

丸山暉 彦*1.菅和 生*2

\section{Application of Rubber Material (Asphalt Rubber) for Road Pavements}

Teruhiko MARUYAMA *1 ${ }^{*}$, Kazuo SUGA ${ }^{* 2}\left({ }^{1}\right.$ Department of Civil and Environmental Engineering Nagaoka University of Technology Nagaoka, Niigata 940-2188, JAPAN, ${ }^{2} \mathrm{R} \&$ D Department Yokohama Rubber Co., LTD 2-1 Oiwake, Hiratsuka, Kanagawa 254-8601, JAPAN)

Asphalt rubber (AR) is a blend, which includes $5-23 \mathrm{wt} \%$ of rubber component, of asphalt cement, reclaimed tire rubber, and certain additives.

In this study, the samples have been prepared by so-called "wet process", which smoothly caused swelling and reaction of the rubber with hot asphalt cement.

AR provides high quality road condition such as thermal cracking and rutting free surface, high skid resistance, low road noise, and so on.

We have researched the factors which affect swelling and degradation of crumb rubber in the asphalt. Then, we can apply the result for the design of Japanese AR pavement, which is required premium grade quality.

Key Words : Crumb rubber, Asphalt rubber, Asphalt pavement

\section{1. アスファルトラバーの開発経緯}

日本では年間約 1 億本の廃夕イヤが発生する．その約半 数はセメント，製紙産業等の熱源としてサーマルリサイク ルに，約 2 割が更生タイヤ等のマテリアルリサイクルに用 いられている。しかし, 約 1 割は流通在庫・使途不明とな っており，一部は不法投棄・野積みなどの問題を起こして いる1)。これらを解消するには，廃夕イヤ・ゴムの新たな マテリアルリサイクル技術を開発する必要があり，道路に 適用されている米国のアスファルトラバー(以下，AR)が 着目されている。現地調查の結果, ARを用いた舗装は日 本でも適用可能な機能を有する舗装と考えられる。“日本 アスファルトラバー研究会 (日本AR研)” が発足して, そ の技術開発が進んで㧍り, 米国ARの動向や日本での現況 について紹介する.

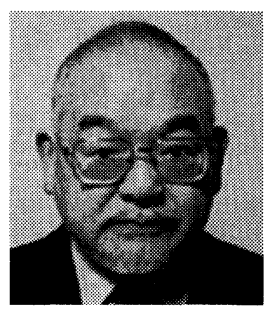

*1 長岡技術科学大学 工学部 (環境・建設系) (テ940-2188 長岡市上富岡町 1603-1) 教授. 日本アスファルトラバー研究会 委員長. 1971年, 東京工業大学大学院修士課程修了. 1973 年, 東京工業大学理工学部助手. 専門 は, 舗装の構造設計・安全設計, 舗装材料 の開発，建設副産物のリサイクル，交通管 理, 騒音・振動設計, 消融雪技術の開発. (社)土木学会舗装工学委員会委員長

\section{2. 米国ARの動向}

\subsection{ARの定義と特徴}

ASTM D8-88では，ARは 15\%以上のゴムを膨潤した 状態で含むアスファルトとある2). Rubber Pavements Association(RPA)では，“アスファルト $80 \%$ ，ゴム $20 \%$ のバインダー”とシンプルである. 両定義共にゴム粉をア スファルトで予め混合し，膨潤熟成する製法，いわゆる
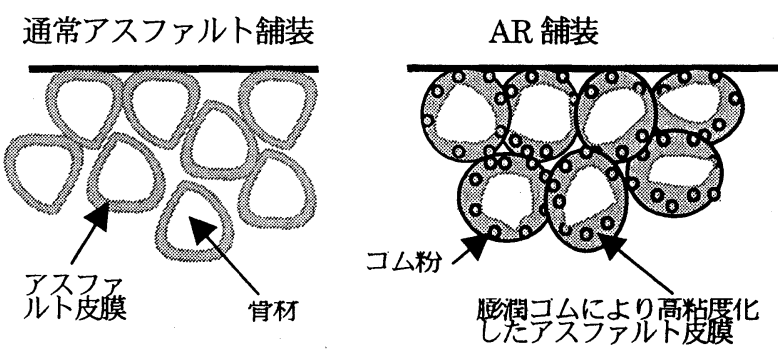

Figure 1 Schematic of AR pavement

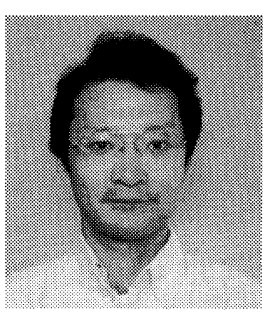

*2横浜ゴム侏研究部 ( $7254-8601$ 平塚市追分 $2-1) .1988$ 年, 九州工業大学大学院環境工 学科修士課程修了. 1988年, 横浜ゴム秼入 社. 専門は, 高分子化学, 分析. 
Wet Process Asphalt Rubberを指す.

Figure 1に，膨潤したゴム粉 $(0.4 \sim 2.0 \mathrm{~mm}$ 径)でアスフ アルトが高粘度化し，骨材周りに厚い皮膜(最大で 4 倍)を 形成した模式図を示す。これにより骨材同士の噛み合せが 強化され，耐クラック性など舗装性能が大幅に向上する.

\subsection{AR開発の歴史と普及状況}

ARは1966年にCharlie Macdonaldが最初に開発し，道 路補修材として使用した。その後, SAMI(Stress Absorbing Membrane Interlayer)などのクラック伝播改良手段 に使われ，70年代に入って密粒系舗装，OGFC (Open Graded Friction Course)などのアスファルト合材に用い られ普及が進んだ。連邦は，野積み夕イヤ削減を目指し， AR 使用を義務付けた法律 (ISTEA) を 90 年代初めに制定 したが，検討段階の州の反対のため普及は滞り，数年で廃 案となった。この後，ARに関する特許が切れたことによ り，ARの普及が進んだ.

アリゾナ，カリフォルニア，フロリダ，テキサスの南部 4 州に普及が偏っているが, 気候的制約がある訳ではなく, アリゾナの寒冷高地やカナダ(アルバータ州)でも普及して いる ${ }^{3)}$. 南部 4 州の普及の推移を Figure 2 に示す.

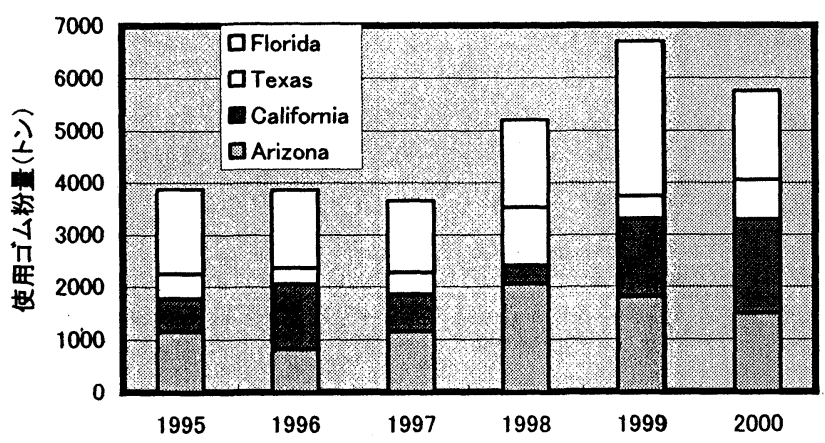

Figure 2 Usage of Crumbled Rubber for AR in USA

この他，改質アスファルトと同じプレミックス製造方式 の ARが 1.4 万トン $(2003$ 年)あり，今後 ARを導入してい く州ではこちらが主流になると予想される，全米では，約 7 万トンのゴム粉が AR 舗装に使用されている。これは全 米で発生する廃夕イヤ約 2.8 億本/年の約 $5 \%$ に相当する.

\subsection{ARの種類}

ARは，Table 1に示すようにゴム粉の高濃度タイプと 低濃度タイプに分かれる.前者は発祥の地アリゾナを始め, カリフォルニア等西部の州で使用され，粗めのゴム粉 (約 $1.4 \mathrm{~mm}$ ) をアスファルトに対し $14 \sim 23 \%$ 使用する。耐ク ラック性や耐轍性が向上するため, 表層舖装厚を低減し, 初期及び長期メンテナンスコストを削減できる。また，道 路騒音も最大数 $\mathrm{dB}$ 低隇でき, 乗り心地がよく, 道路周辺 住民に迷惑をかけない“低騒音”に特長がある ${ }^{4)}$.

後者はフロリダ，サウスカロライナ等東部の州で採用さ れ，特許に抵触するアリゾナプロセスを回避して，細粒径
Table 1 Varieties of AR-pavement \& Rubber Particle Size in USA

\begin{tabular}{|c|c|c|c|}
\hline \multirow[t]{2}{*}{ State } & \multirow[t]{2}{*}{ Applications } & \multicolumn{2}{|c|}{ Rubber of Binder } \\
\hline & & Weight $\%$ & Particle size \\
\hline Arizona & GGFC, OGFC & $20 \%$ & $2.00 \mathrm{~mm}$ (\#10mesh) \\
\hline California & $\begin{array}{l}\text { 3-Layer System } \\
\text { (DGFC, SAMI, OGFC) }\end{array}$ & $14-23 \%$ & \\
\hline Florida & ARMI, DGFC, OGFC & $5-20 \%$ & $\begin{array}{l}850 \mu \mathrm{m} \text { (\#20mesh) } \\
425 \mu \mathrm{m} \text { (\#40mesh) }\end{array}$ \\
\hline South Carolina & DGFC, SAMI, OGFC & $10-20 \%$ & $425 \mu \mathrm{m}$ (\#40mesh) \\
\hline Texas & GGFC, OGFC & $10-20 \%$ & $\begin{array}{l}2.00 \mathrm{~mm} \text { (\#10mesh) } \\
1.18 \mathrm{~mm}(\# 16 \mathrm{mesh})\end{array}$ \\
\hline
\end{tabular}

Key

GGFC $=$ Gap Graded Friction Course

SAMI $=$ Stress Absorbing Membrane Interlayer OGFC $=$ Open Graded Friction Course

$\mathrm{ARMI}=$ Asphalt Rubber Membrane Interlayer

DGFC $=$ Dense Graded Friction Course

のゴム粉 (40メッシュ，約 $0.4 \mathrm{~mm}$ )を少量 (密粒系で $5 \%$, OGFCで $12 \%)$ 使用する形をとった。耐久性改良効果は小 さいが，ゴムとアスファルトの混合装置の投資額が前者の 半分で済む利点がある。

更に，米国では ARを使用することで，排水性舗装が製 造可能となり，水跳ね・スリップ防止の“安全性”も大き く向上した。

\section{4 米国ARの動向を踏まえた課題}

日本で ARを普及するには，以下の課題が考えられ，対 策が必要である。

(1)かく拌つき混合装置の設備投資が必要．費用は数千 万 $($ 移動型 $) \sim 1$ 億円 (固定タイプ)で，バインダー供 給方式はプレミックスが低コスト

(2)本質的に高粘度であるため，冬季施工しづらい.ア リゾナ等では徐々に克服されつつあり，日本でも寒 冷地対策が必要。

(3)フロリダ州では再生合材の使用で問題があり，再生 合材の利用が必須.

(4)施工条件により揮発分やゴム特有の臭気対策が必 要。ただし，少量の芳香剂混入で解決できる場合も ある．揮発成分中には有害物質は観測されていない が，今後検証が必要。

(5) 2 次リサイクル性が必要.

\section{ARバインダーの挙動}

ARを日本に適用する際，バインダニ物性や合材物性と ともに施工性や供給性に影響を与えるバインダー粘度，及 びゴム粉の変化を把握することは極めて重要である．日本 の原材料を混合・かく捧·熟成した場合，どのような粘度 挙動やゴム粉が変化を示すのか検討を加えた.

\section{1 使用材料及び混合·熟成方法}

ARバインダー作製に用いたゴム粉をTable 2 に示す。 ゴム粉は天然ゴム主体のトラック・バスタイヤからのゴム 
Table 2 Kinds of Rubber Particles for AR

\begin{tabular}{|c|c|c|}
\hline 名 称 & ゴム粉サイズ & $\begin{array}{l}\text { 備 考 } \\
\end{array}$ \\
\hline TB $0.4 \mathrm{~mm}$ & $0.4 \mathrm{~mm}$ 程度 & \multirow{3}{*}{ トラック・バスタイヤ } \\
\hline TB $0.7 \mathrm{~mm}$ & $0.7 \mathrm{~mm}$ 程度 & \\
\hline TB $1.0 \mathrm{~mm}$ & $1.0 \mathrm{~mm}$ 程度 & \\
\hline PS $0.4 \mathrm{~mm}$ & $0.4 \mathrm{~mm}$ 程度 & \multirow{3}{*}{ 乗用車タイヤ } \\
\hline PS $0.7 \mathrm{~mm}$ & $0.7 \mathrm{~mm}$ 程度 & \\
\hline PS $1.0 \mathrm{~mm}$ & $1.0 \mathrm{~mm}$ 程度 & \\
\hline 米国ゴム粉 & $1.4 \mathrm{~mm}$ 程度 & 乗用車夕イヤ \\
\hline 台湾ゴム粉 & $0.6 \mathrm{~mm}$ 程度 & \\
\hline
\end{tabular}

粉 (TB) と合成ゴム主体の乗用車夕イヤからのゴム粉 (PS) の 2 品種を, アスファルトは, ストレートアスファルト （以下，Stas60/80，Stas80/100）を用いて評価した。参考 のため米国及び台湾からも原材料 (ゴム粉, アスファルト) を入手し評価した。混合方法はStas60/80及びStas $80 / 100$ の各 $700 \mathrm{~g}$ を容量 1 リットルの SUS ビーカーで $200{ }^{\circ} \mathrm{C}$ まで 加熱，沉用かく汼羽根を用いて，約 $15 ３ 0$ 分かく捧しな

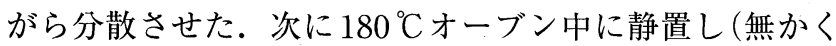
拌), 1 〜 時間熟成した.

\section{2 評価方法}

粘度測定はビスコテスタ-VE- 04 粘度計(リオン製)を用 いて標準条件 $180 \pm 1{ }^{\circ} \mathrm{C}$ で実施した。速度依存性について はブルックフィールド粘度計 $(\mathrm{B} \cdot \mathrm{F}$ 粘度計) を用いて 5 $100 \mathrm{rpm} / 180{ }^{\circ} \mathrm{C}$ で測定した.

ゴム粉の膨潤挙動は，0.5〜 $1.0 \mathrm{~mm} \times 2 \mathrm{~mm} \times 2 \mathrm{~mm}$ のゴ ム片をアスファルトと一緒にパンに入れて，TMAにより 温度ーゴム接触膨潤測定を行った。

\section{3 実験結果}

\section{3 .1 ゴム粉サイズ及び熟成と粘度}

$\mathrm{ASTM}^{2)}$ ではAR バインダーの粘度範闻は1500〜 $5000 \mathrm{mPa} \cdot \mathrm{s} / 350^{\circ} \mathrm{F}$ と規定されているが，ゴム粉サイズを 変更した場合の粘度変化をFigure 3 に示す．ゴム粉サイ ズは小さいほど,配合量は多いほど高い粘度を示している. また，熟成による粘度変化を Figure 4 に示すが，熟成に よって粘度はさらに高くなっている.アスファルト種で見 ると, Stas80/100より Stas60/80をベースにした方が高粘 度になる傾向が認められる。

Stas60/80をべースにした場合， $0.4 \mathrm{~mm}$ サイズで約

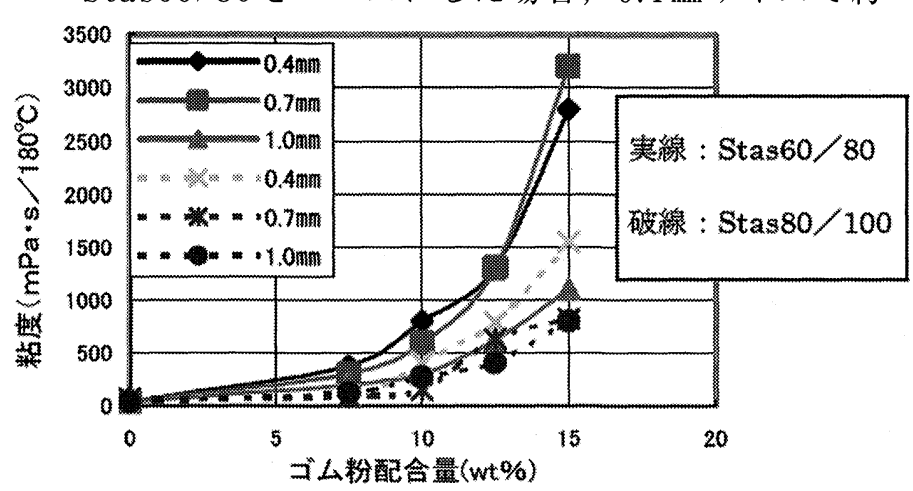

Figure 3 Relationship between Viscosity and Rubber Particles

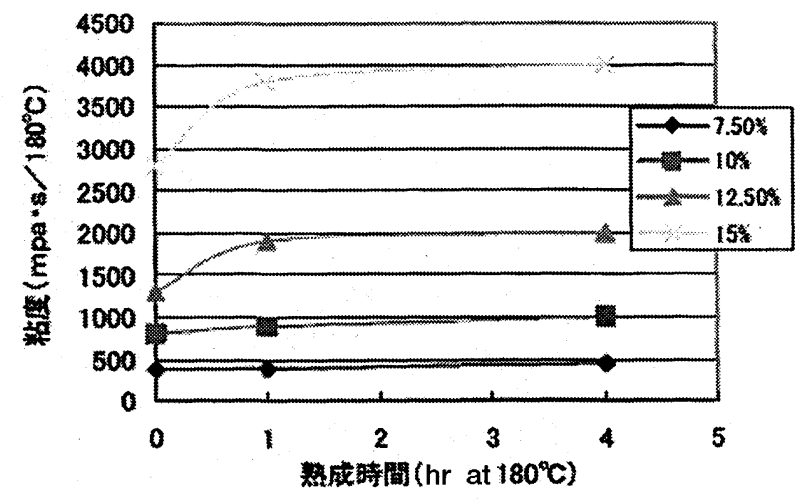

Figure 4 Viscosity Change by Aging

$15 \mathrm{wt} \%$ 前後で ASTM の粘度範囲 $1500 \sim 5000 \mathrm{mPa}$ • $\mathrm{S} / 180^{\circ} \mathrm{C}$ に入り，15wt\%を超えると急激に粘度上昇する ことが確認できる。TBゴム粉と PSゴム粉の比較におい てはTBゴム粉の方が高粘度になる傾向がある.

\subsubsection{ARバインダーの速度依存性}

$\mathrm{AR}$ バインダー $(\mathrm{Stas} 60 / 80)$ の粘度の速度依存性をブル ックフィールド粘度計で測定した結果を Figure 5 に示す. 結果は改質 II 型や高粘度バインダと傾向が違い, AR バイ ンダーは速度依存性が大きい(チクソ性がある)ことが確認 された。これは A Rバインダーの持つ大きな特徵と考えら れる。

\section{3 .3 ARバインダー中のゴム粉の挙動}

ゴム自体の熱膨張は, ゴム種によらず, 室温から $180{ }^{\circ} \mathrm{C}$ までの加熱で，約 $4 \%$ 膨張した. アスファルトと併用する

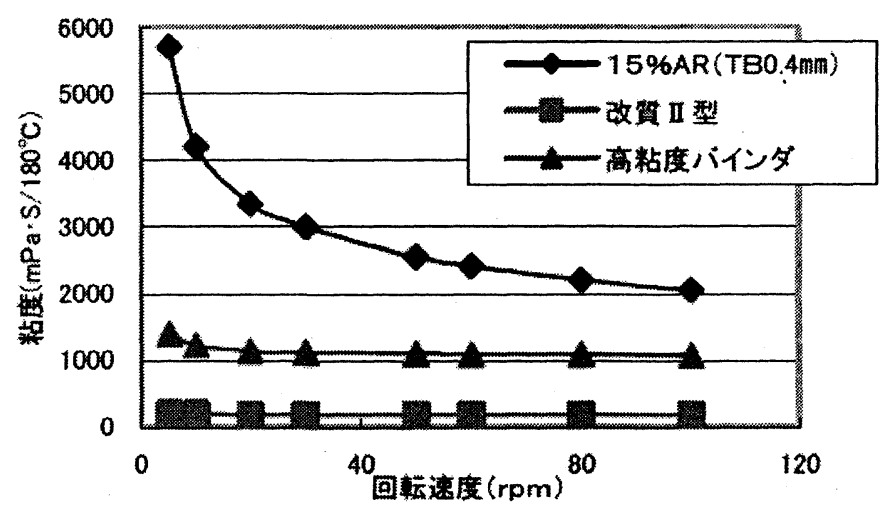

Figure 5 Shear Rate Dependency of Viscosity of AR

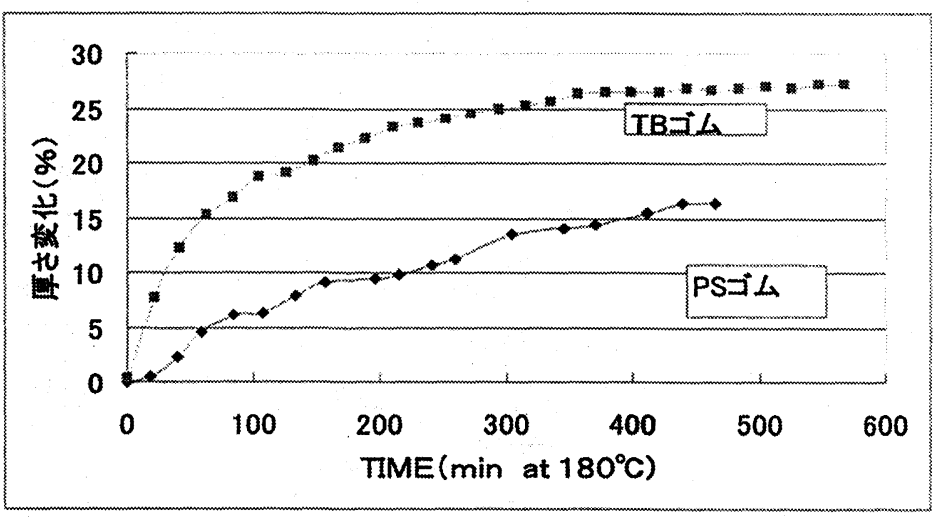

Figure 6 Swelling Tendency of Rubber Particles in AR by Temperature 
と，TBゴムがPSゴムの 2 倍近く膨張した (Figure 6)。ま た，アスファルト種によっても膨張率が異なり，粘度調整 を図る上で，考慮が必要である。

\section{ARの道路舗装への適用}

\section{1 密粒度混合物, SMA, 再生合材へのARの適用}

$\mathrm{AR}$ をバインダーとした密粒度アスファルト混合物（以 下，AR密粒混合物) および砕石マスチック混合物 (以下， AR-SMA) と，従来のストレートアスファルト（以下，ス トアス) 抒よび改質 II 型アスファルト（以下，改質 II 型）を 用いた混合物の混合物性状を比較し，AR適用の可能性を 検討した。更に，国内で生産されるアスファルト混合物の うち約 $2 / 3(2002 \text { 年度の実績で } 65.7 \%)^{5)}$ は再生アスファル 卜混合物であるため，ARをアスファルト混合物用のバイ ンダーとして利用する場合，新規アスファルト混合物（以 下，新規混合物)だけでなく再生アスファルト混合物にも 利用できることが望ましい，そこで，ARを新規バインダ 一とした再生アスファルト混合物 (以下，AR再生混合物） の性状をストアスや改質 II 型を用いた新規混合物と比較し て，再生アスファルト混合物への $\mathrm{AR}$ 適用の可否を評価し た.

\section{2 使用材料および試験項目・条件}

\subsection{1 使用材料}

本検討に使用した ARは，ストアス60/80にトラック・ バス用タイヤのゴム粉を $8 \% ， 12 \% ， 15 \%$ の 3 水準で添 加し， $180^{\circ} \mathrm{C} て ゙ 1$ 時間かく找熟成したものである。 また, $\mathrm{AR}$ 再生混合物はゴム粉 $15 \%$ 添加した密粒度アスファルト 混合物で，再生骨材配合率を $0,30 ， 60 \%$ の 3 水準とした。

\section{2 .2 試験項目}

動的安定性 (DS) の比較のために，ホイールトラッキン

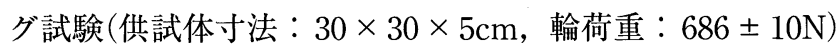
を，低温時の変形追従性を比較するために，単純曲げ試験 （供試体寸法： $5 \times 5 \times 30 \mathrm{~cm}$, 載荷速度 : $50 \mathrm{~mm} / \mathrm{min}$, 温度：-10〜 $15{ }^{\circ} \mathrm{C}$ ，スパン：200mm)を行った.

\section{3 試験結果}

$\mathrm{AR}$ 密粒混合物はストアスよりバインダー量は多くな り，動的安定度 (DS) も大きく向上することが認められた。

SMA は骨材分離防止のため植物繊維 (以下，MC)を 0.3 〜 0.5\%程度添加する場合が多く，ストアス $60 / 80$ および 改質 II 型を使用した場合は MC0.3\%を添加し，ARを使用 した場合は無添加とした。一方，動的安定度は MCを添加
することなく，ゴム粉添加量を調整することで，改質 II 型 と同程度の值が期待できるとともに，低温状態での曲げ追 従性に優れた混合物であることが分かった(Table 3).

AR 再生混合物の DS は，再生骨材配合率の増加に伴い 若干増大する傾向にあり，再生骨材配合率 $30 \sim 60 \%$ 程度 (併設加熱混合方式の再生アスファルト混合所で通常設定 される再生骨材配合率の範囲) では改質 II 型を用いた新規 混合物とほほ同等である (Figure 7)。

よって, 疲労抵抗性・耐摩耗対策として重交通箇所の表 層に適用することができる。

\section{5. 実用化に向けて}

日本AR研究会では，AR混合装置 (Max3.0t)を作製し， 2004 年 5 月以降， 2 箇所で試験施工を行った (Figure 8). 従来の機械設備を用いて，合材：施工ができることを確認 し，路面は良好である。

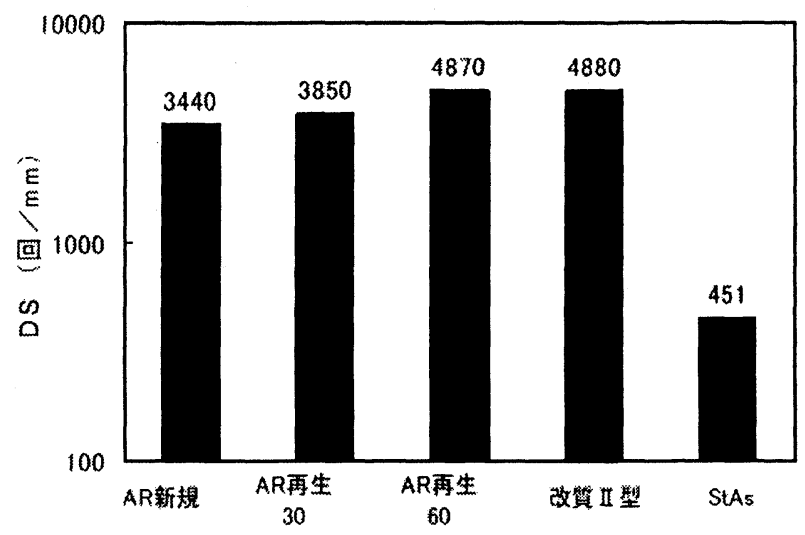

Figure 7 Dynamic Stability of AR recycled pavement

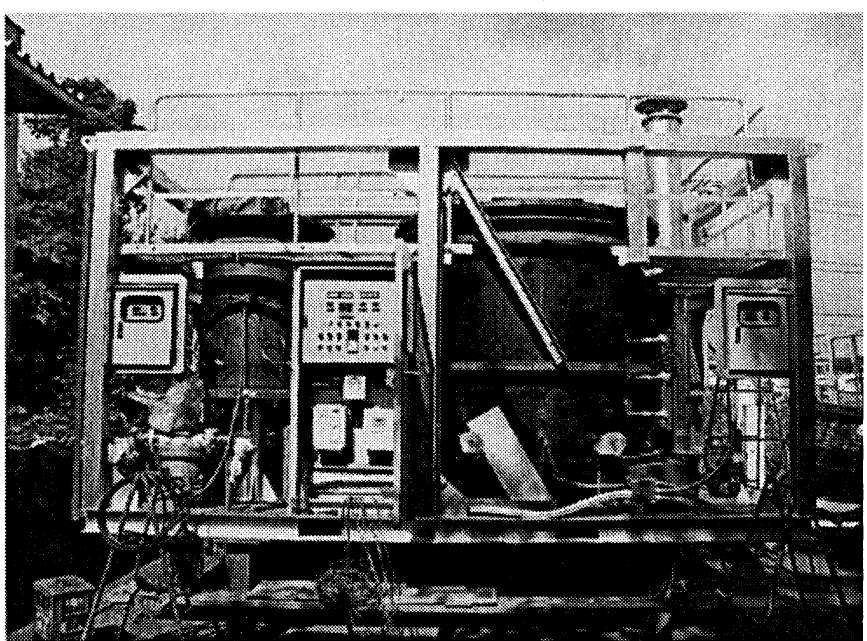

Figure 8 Appearance of AR Mixing System

Table 3 Durability of AR-SMA

\begin{tabular}{|c|c|c|c|c|c|}
\hline 種類 & \multicolumn{2}{|c|}{$\mathrm{MC} 0.3 \%$ 添加 } & \multicolumn{3}{|c|}{ MC無添加 } \\
\hline 項目 & ストアス $60 / 80$ & 改質 II 型 & TB $8 \%$ & TB $12 \%$ & TB $15 \%$ \\
\hline アスファルト量 $(\%)$ & 5.8 & 6.0 & 5.9 & 6.5 & 6.7 \\
\hline 供試体密度 $\left(\mathrm{g} / \mathrm{cm}^{3}\right.$ ) & 2.391 & 2.402 & 2.401 & 2.383 & 2.381 \\
\hline 動的安定度 (回/mm) & 2800 & 4800 & 5800 & 3200 & 4200 \\
\hline
\end{tabular}




\section{6. 今後の進め方・課題}

ARを利用した舗装は, 廃タイヤのリサイクルにとどま らず，舗装の機能(高耐久性，高スキッド，低騒音など）を 改善する可能性を秘めている. 今後, ARの作用機構を解 明するとともに, 排水性舗装と呼ばれる低騒音・走行安全 性に優れた最近注目されている舗装への適用を図り, 将来, 生活道路から主要幹線道路まで幅広い用途で利用できる 「夢の舗装材料」を目指したい.

\section{References}

1) Japan Automobile Tyre Manufacturers Association:"Nippon no Tire Sangyo 2003", Japan Automobile Tyre Manufacturers Association, Tokyo, p.17 (2003)
2) ASTM D6114-97, ASTM International, PA (2002)

3 ) Usmani, A. M.: Asphalt Science and Technology, Marcel Dekker, NY, p.385 (1997)

4 ) Takeichi, H., Maruyama, T., Hokari, K., Nomura, K., Yamada, Y:: Japan Society of Civil Engineers, 59th JSCE Annual Meeting, 5-557, p.1111 (2004)

5 ) Japan Asphalt mixture Association: Asphalt Gozai, No.68 (2003)

\section{日本語表記参考文献}

1) 日本自動車夕イヤ協会：日本の夕イヤ産業 2003,p.17 (2003), 日本自動車夕イヤ協会, 東京

4 ）武市秀雄, 丸山輝彦, 帆苅浩三, 野村健一郎, 山田佳則：土木 学会第 59 回年次学術講演会要旨集, 5-557, p.1111, (2004)

5 ）日本アスファルト合材協会：平成 14 年度アスファルト合材の現 況, アスファルト合材, No.68 (2003)

\section{本会発行出版物ご案内}

\section{ゴム工業便 覧 \\ （第四版） \\ 定価 36,750円（税込） \\ 会員価格 33,075 円 (税込) \\ B 5 版 1350 頁 \\ 送 料 (当方負担)}

\section{(1994.1 発行)}

$\left(\begin{array}{l}コ ゙ ム の \text { 物性から製造, 加工，製品，測定，分析に至るまでを，現在第一線で活躍中の斯 } \\ \text { 界の権威者 } 150 \text { 余名の執筆陣により，最も新しいゴムの科学・技術を提供いたします. }\end{array}\right)$

* お申込の場合は, 必要事項(送付先住所, 勤務先, 氏名, 電話番号など)をご記入のうえ, FAXして下さい. 